\section{Assessments of Bare-root Liner Quality and Purchasing Decisions Made by Green Industry Professionals}

\author{
Andrew Jeffers \\ Plant Sciences Department, The University of Tennessee, 2431 Joe Johnson \\ Drive, 252 Ellington PSB, Knoxville, TN 37996-4561
}

\author{
Marco Palma \\ Department of Agricultural Economics, Texas A\&M University, College \\ Station, TX 77843
}

\author{
William E. Klingeman ${ }^{1}$ \\ Plant Sciences Department, The University of Tennessee, 2431 Joe Johnson \\ Drive, 252 Ellington PSB, Knoxville, TN 37996-4561
}

\section{Charles Hall \\ Department of Horticultural Sciences, Texas A\&M University, College Station, TX 77843}

\section{David Buckley}

Forestry, Wildlife and Fisheries Department, The University of Tennessee, 2431 Joe Johnson Drive, Knoxville, TN 37996-4561

\section{Dean Kopsell \\ Plant Sciences Department, The University of Tennessee, 2431 Joe Johnson Drive, 252 Ellington PSB, Knoxville, TN 37996-4561} Additional index words. first-order lateral roots, green industry, marketing, product attributes,
uniformity

\begin{abstract}
Production of high-quality nursery liners has long been a foundation principle for enabling success and business longevity in the competitive nursery industry. Unfortunately, many different characteristics can be used to define liner "quality," ranging from physiological parameters measurable in scientific studies field establishment success and transplant production performance to gut-level hunches on the part of growers. A more complete understanding of what buyers are looking for in a bare-root liner would significantly enhance the success of producers in meeting the demands of endusers. As a result, a choice study involving a point-of-purchase simulation was designed to assess preferences of green industry professionals when viewing bare-root $1+0$ nursery liners. A conjoint design was used for this study and involved six key attributes of liners: 1) number of first-order lateral roots (FOLR); 2) price; 3) production region; and uniformities of 4) height; 5) canopy density; and 6) liner caliper. A visual survey based on a large, color graphic depicting six distinct bare-root $1+0$ liners with different combinations of attributes was administered together with a demographic questionnaire at four different green industry tradeshows and extension grower education and outreach venues in the southeastern United States. Results from 248 completed surveys corroborated previously reported results suggesting that high FOLR is the most important attribute influencing preference for $\mathbf{1}+\mathbf{0}$ liner products followed by uniform liner height and canopy density. Contrary to a priori expectations, neither price nor region of production substantially influenced product preference. Utility values were calculated for each attribute level using outputs from the experimental model. These values can be used by growers to adjust production methods to improve liners with attributes that end-users value most. In addition, growers will be able to better estimate product ratings, redirect marketing efforts, and assess sales potential for various bareroot $1+0$ liner products in U.S. markets.
\end{abstract}

\footnotetext{
Received for publication 16 Jan. 2009. Accepted for publication 24 Mar. 2009.

${ }^{1}$ To whom reprint requests should be addressed; e-mail wklingem@utk.edu.
}

To produce high-quality finished nursery stock, maintain a competitive edge, and build economic market share, ornamental plant producers are encouraged to start production cycles using "high-quality" plant liners. However, liner quality is subjective and seldom clearly defined for growers. Many different physiological and morphological parameters can be used to define quality. Furthermore, quality perceptions vary between liner buyers. At the outset of this project, we informally surveyed green industry professionals and liner producers to better understand their beliefs about liner quality. For example, growers stated they simply evaluate overall appearance of liner stock, checking only for signs of disease or insect damage within a purchase (G. Griffith, Wilkerson Mill Nurseries, personal communication, 4 Jan. 2007; J. Depey, Spring Meadow Nursery, personal communication, 4 Jan. 2007), whereas others stated generally that uniformity was very important (D. Shadow, Shadow Nurseries, personal communication, 16 Feb. 2007; S. Moore, Oak View Liners, personal communication, 16 Feb. 2007) or that west coast (e.g., Oregon) liners were higher quality than liners from southern sources without specifying more than general uniformity.

Current American Nursery and Landscape Association (ANLA) American Standards for Nursery Stock do not specifically address attributes of quality often described by bare-root liner buyers and growers (see Sections 6: Young Plants, 9: Understock, and 10: Seedling Trees and Shrubs). For example, Sections 10.2.1. Deciduous or hardwood(s) and 10.2.2. Coniferous evergreen(s) describe just minimum caliper, height, and root length requirements for seedlings (ANLA, 2004). Indeed, quality perception is an abstract, qualitative concept and informal interviews with green industry professionals suggest that many liner growers and buyers have their own preferences when assessing quality of the bare-root liners that they grow and buy.

In addition to economic considerations, most growers are likely to choose some plant morphological attribute as a grading criterion for liner stock. Morphological attributes might include caliper measurements, height, root collar diameter (RCD), or the number of first-order lateral roots (FOLR), which are defined as roots greater than $1 \mathrm{~mm}$ in diameter that emerge $30 \mathrm{~mm}$ below the root collar (Kormanik et al., 1998). Such parameters can be easily observed and require minimal time and employee training to assess. High FOLR number and larger RCD provide growth and survival advantages as suggested by studies that link these traits to better field survivability and increased plant vigor (Clark et al., 2000; Dumroese et al., 2005; Jacobs et al., 2005; Kormanik et al., 1998; Schultz and Thompson, 1996; Thompson and Schultz, 1995; Wilson and Jacobs, 2006). Although many different morphological attributes can be indicators of "quality" and some can influence first-year transplant performance, product preferences based on perceptions of quality are poorly understood and are also expected to be critically important to product acceptance in the market (Clark et al., 2000).

To better assess green industry professional perceptions of nursery liner quality and other factors influencing purchasing decisions, we can design a choice experiment using conjoint analysis, sometimes called 
tradeoff analysis, which is a survey technique allowing multiple product attributes and attribute levels to be analyzed simultaneously. The process forces participants to tradeoff certain product attributes for others, thus helping limit sample bias (Mason et al., 2008). In turn, respondent preferences for different product options are broken down to determine the respondents' inferred utility function and relative importance of each attribute of a product (Curry, 1996; Wally et al., 1999; Wirth et al., 2007). After ranking each product with varying attributes, conjoint statistical analyses produce utility values for each product attribute, thereby allowing researchers to make inferences about effects of attribute interactions with respondent product rating (Curry, 1996; Wirth et al., 2007). A previous study applied this technique to gauge market viability of blue-flowering geraniums, an ornamental commodity that currently does not exist. Behe et al. (1999) assessed consumer acceptance for a blueflowering geranium plant by providing that hypothetical option as a holdout product within a conjoint study. Contrary to a priori expectations that blue flower color in geraniums could become a successful new floricultural niche product, respondents to the study did not prefer the blue-flowering geranium form.

Our limited understanding about how different bare-root liner attributes influence qual- ity perceptions as well as lack of integration of key quality attributes into industrywide standards for bare-root liners can translate to significant lost opportunity costs. Therefore, the objective of this study was to determine the relative importance of bare-root nursery liner product attribute levels in price, U.S. region of production, FOLR number, and uniformities of liner height, canopy density, and caliper, professionals' evaluation of nursery liner stock just before making hypothetical pointof-purchase decisions.

\section{Materials and Methods}

To address this study's objectives, we define a liner as a tree seedling grown for 1 year either in a seedbed or in field soil and then lifted and bare-rooted for sale or transplant as nursery planting stock. This type of seedling would be referred to as a $1+0$ seedling in commercial trade because it was allowed to grow for 1 year in the original seedbed or field and 0 years in a transplant bed (Garber et al., 1999). Based on contemporary liner production practices, plant quality and outplant studies as well as informal phone interviews with retail and wholesale nursery liner buyers, we focused on six key plant attributes that appear to influence buyer perceptions of the quality and value of bare-root nursery liner stock. U.S. region of production was included with tested attributes to assess whether that parameter could impart a potentially confounding influence on liner preference.

To obtain respondent feedback about identified bare-root liner attributes, our sampling strategy integrated a paper questionnaire with a large, visual graphic that portrayed color images of disease and pest injury-free nursery liner products with different combinations of product attributes. Bare-root liners are typically packaged in bundles, so respondents were told that individual liners show were representative of all liners within a hypothetical bundle (Fig. 1). The graphic display poster measured $1.4 \mathrm{~m}$ wide $\times 0.9 \mathrm{~m}$ tall. By conducting the survey in this manner, the assumption was made that we could elicit professional assessments and decisions similar to those made either just before actual liner purchases or on receipt and examination of bare-root nursery liner stock. Images included in the graphic depicted pest and disease injuryfree bare-root $1+0$ Nuttall oak liners (Quercus nuttallii Palmer). The root and shoot appearance of this species during dormancy is representative of a wide variety of tree species. Attributes that varied between different images on the graphic display were FOLR number, price, region of production and caliper, canopy density, and height uniformity (Table 1; Fig. 1).

The combination of these attributes and their respective attribute levels yields $2 \times 2 \times$ $2 \times 3 \times 3 \times 3=216$ different product profiles.
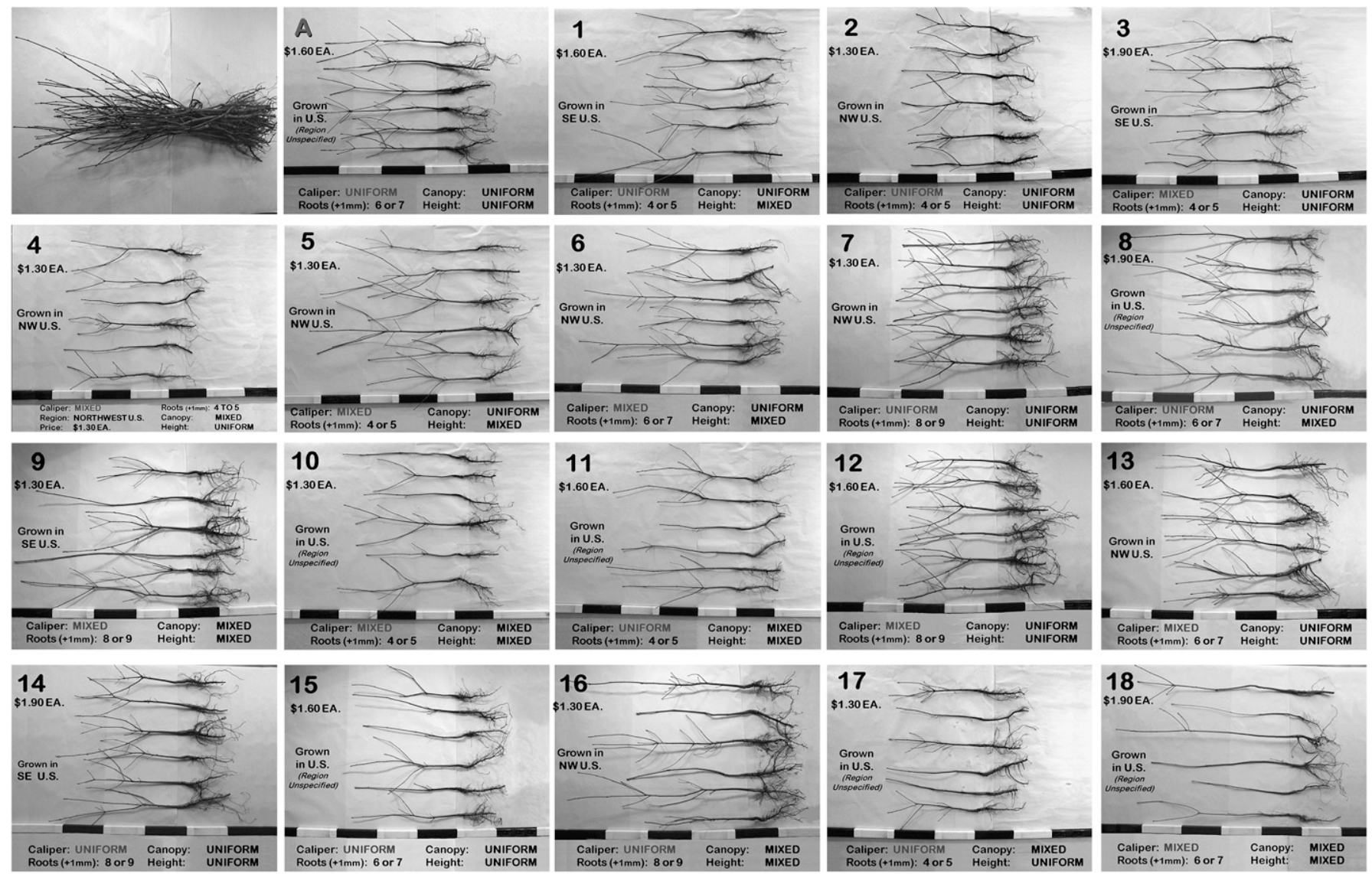

Fig. 1. Scaled-down depiction of the visual survey nursery liner product images rated by respondents participating in a study of green industry professional perceptions about nursery liner quality. The actual graphic display was presented as a $1.4 \mathrm{~m}$ wide $\times 0.9 \mathrm{~m}$ tall color poster. 
Table 1. Fractional factorial design, as described by SPSS, of attributes and attribute levels associated with $1+0$ bare-root nursery liners that were visually tested by conjoint survey analyses to quantify relative importance of each character to hypothetical point-of-purchase acceptance by respondents.

\begin{tabular}{|c|c|c|c|c|c|c|c|}
\hline Product & $\begin{array}{c}\text { First-order lateral } \\
\text { root number }(\mathrm{FOLR})^{\mathrm{z}}\end{array}$ & $\begin{array}{l}\text { Liner ht } \\
\text { uniformity }\end{array}$ & $\begin{array}{c}\text { Liner caliper } \\
\text { uniformity }\end{array}$ & $\begin{array}{c}\text { Liner canopy } \\
\text { density uniformity }\end{array}$ & Price per liner & $\begin{array}{l}\text { U.S. region } \\
\text { of production }\end{array}$ & $\begin{array}{l}\text { Position } \\
\text { in display }\end{array}$ \\
\hline 1 & 4 to 5 roots & Mixed & Mixed & Mixed & $\$ 1.30$ & Unspecified & 10 \\
\hline 2 & 4 to 5 roots & Mixed & Mixed & Uniform & $\$ 1.30$ & Northwestern & 5 \\
\hline 3 & 4 to 5 roots & Mixed & Uniform & Mixed & $\$ 1.60$ & Northwestern & 11 \\
\hline 4 & 4 to 5 roots & Mixed & Uniform & Uniform & $\$ 1.60$ & Southeastern & 1 \\
\hline 5 & 4 to 5 roots & Uniform & Mixed & Mixed & $\$ 1.90$ & Northwestern & 4 \\
\hline 6 & 4 to 5 roots & Uniform & Mixed & Uniform & $\$ 1.90$ & Southeastern & 3 \\
\hline 7 & 4 to 5 roots & Uniform & Uniform & Mixed & $\$ 1.30$ & Unspecified & 17 \\
\hline 8 & 4 to 5 roots & Uniform & Uniform & Uniform & $\$ 1.30$ & Northwestern & 2 \\
\hline 9 & 6 to 7 roots & Mixed & Mixed & Uniform & $\$ 1.30$ & Northwestern & 6 \\
\hline 10 & 6 to 7 roots & Mixed & Uniform & Uniform & $\$ 1.90$ & Unspecified & 8 \\
\hline 11 & 6 to 7 roots & Uniform & Mixed & Uniform & $\$ 1.60$ & Northwestern & 13 \\
\hline 12 & 6 to 7 roots & Uniform & Uniform & Mixed & $\$ 1.30$ & Southeastern & 15 \\
\hline 13 & 8 to 9 roots & Mixed & Mixed & Mixed & $\$ 1.30$ & Southeastern & 9 \\
\hline 14 & 8 to 9 roots & Mixed & Uniform & Mixed & $\$ 1.90$ & Northwestern & 16 \\
\hline 15 & 8 to 9 roots & Uniform & Mixed & Uniform & $\$ 1.60$ & Unspecified & 12 \\
\hline 16 & 8 to 9 roots & Uniform & Uniform & Uniform & $\$ 1.30$ & Northwestern & 7 \\
\hline $\mathrm{HO}_{1}$ & 8 to 9 roots & Uniform & Uniform & Uniform & $\$ 1.60$ & Southeastern & 14 \\
\hline $\mathrm{HO}_{2}$ & 4 to 5 roots & Mixed & Mixed & Mixed & $\$ 1.30$ & Unspecified & 18 \\
\hline
\end{tabular}

${ }^{\mathrm{z}}$ Side roots $1 \mathrm{~mm}$ or greater diam.

SPSS was used to generate a fractional factorial design (SPSS, 2005), which provided an orthogonal subset of 16 attribute levels needed to generate digital images of tree liner product attribute combinations (Table 1; Fig. 1). To obtain the nursery liner product images, $1+$ 0 bare-root Nuttall oak liners were obtained from a local nursery. Liners were first divided into short, medium, and tall height groups and then subdivided within height grades into three FOLR grades: low = four or five FOLR; mid = six or seven FOLR; and high = eight or nine FOLR (after Kormanik et al., 1998). Once segregated, these liner pools were used to select combinations of multiple branched or unbranched specimens with either thin (1 to $4 \mathrm{~mm}$ diameter) or thick ( 5 to $7 \mathrm{~mm}$ diameter) stem calipers. Caliper was measured $\approx 1 \mathrm{~cm}$ above the root collar. Liners were photographed using a digital camera mounted $\approx 1$ $\mathrm{m}$ above the table and images were digitally altered, as needed, using Adobe Photoshop CS2 version 9 (Adobe Inc., San Jose, CA) to emphasize variations in product attributes based on criteria for product profiles as prescribed by the SPSS output (Table 1; Fig. 1). The median price range was chosen by averaging 2006 to 2007 list prices for same-sized bare-root Nuttall oak liners from three wholesale nursery catalogs and online availability lists. Upper and lower price points were set to vary by $\approx 20 \%$.

In addition to the 16 nursery liner product sets, the survey also includes two "holdout" products. In conjoint studies, holdout products are used to measure predictability of the experimental model by comparing the model's predicted utility values with the actual survey respondents' average (Behe et al., 1999; Palma, 2002; Wirth et al., 2007). The first holdout product $\left(\mathrm{HO}_{1}\right)$ had: a high FOLR count (eight or nine roots); uniformity among the height, canopy density and caliper among the liners in the bundle; was grown in the southeastern U.S. region; and had a midrange price of a $\$ 1.60$ per liner. The second holdout product $\left(\mathrm{HO}_{2}\right)$ had a low FOLR count (four or five roots); no uniformity of height, canopy density and caliper among the liners in the bundle; was grown in a unspecified U.S. region; and had a high price of a $\$ 1.90$ per liner (Table 1; Fig. 1).

Surveys were administered to green industry professionals, including liner buyers and growers at the 2007 Southern Nursery Association Trade Show, the 2007 Tennessee Green Industry Field Day, the 2007 Eastern Region Nursery Tour, and the 2008 MidStates Horticultural Exposition. Respondents first provided demographic information such as primary operating location of the business; whether respondents grow, buy, or sell liners; about how many acres they have in total production and about what percentage of that acreage is used for liner production; the company's gross sales and what percentage of those gross sales are obtained from liner sales; the respondent's gender and years of experience in the green industry; the number of suppliers from whom liners are purchased; and the types of liner stock preferred by the respondents. Liner stock options were presented as bare-root, cellpack (plug grown), 3-inch $\left(414-\mathrm{cm}^{3}\right)$ air root-prune container, 4inch $\left(798-\mathrm{cm}^{3}\right)$ rose or band container, 1-gallon (3.78-L) air root-prune container, or a 1-gallon $(3.78 \mathrm{~L})$ trade-standard container (Table 2$).$

To obtain self-stated preferences that respondents expressed for each of our variables, participants were asked to rate each variable (root number, region of production, price, and height canopy and caliper uniformity) on a self-stated Likert scale, in which " 1 " is not very important through " 5 " being very important, when making their nursery liner purchasing decisions. The self-stated preference ranking activity was immediately followed by the visual portion of the survey, in which respondents rated each of the 18 nursery liner product images that depicted variable attributes as dictated by the Conjoint Designer model (Table 1; Fig. 1) using a 1 to 10 Likert scale in which " 1 " signified low personal preference and " 10 " high personal preference for the different liner product attribute combinations.
Data were analyzed using Time Series Processor (TSP) econometric modeling software (TSP International, 2003). Effects coding was used and dummy variables were created such that the $\mathrm{k}^{\text {th }}$ base level in the model is set to -1 instead of 0 , which allowed us to constrain the level of each attribute to sum to 0 (Palma, 2002). Through this technique, the base level of each dummy variable is restricted to an average rather than to a particular category. This allows easier comparison of the values of each dummy variable while at the same time preventing the dummy variable trap (Greene, 1990). When a parameter value is positive and statistically significant, the variable is interpreted to be higher than the average of all categories for that dummy variable. Similarly, when negative and statistically significant, the parameter value falls below the average of all categories for that dummy variable.

The preference utility model for the conjoint analysis can be expressed as follows:

$$
\begin{aligned}
\text { Liner rating }= & f(\text { FOLR number }, \\
& \text { height uniformity, } \\
& \text { caliper uniformity, } \\
& \text { uniformity of canopy } \\
& \text { density, region of } \\
& \text { production, price } \\
& \text { per liner }, \text { and } \\
& \text { other })
\end{aligned}
$$

where:

Rating = preference rating given to hypothetical nursery liner stock and ranges from 1 to 10 ;

FOLR number $=$ the number of roots greater than $1 \mathrm{~mm}$ in diameter: low FOLR $=$ four or five; mid FOLR = six or seven; or high FOLR = eight or nine;

Liner height uniformity $=$ average height of the plants in the liner bundle is relatively the same: uniform or not uniform; 
Table 2. Demographic information provided by respondents participating in a survey investigating quality perceptions and ratings for $1+0$ bare-root nursery liner products at selected regional nursery trade shows and educational venues.

\begin{tabular}{|c|c|}
\hline Item & $\begin{array}{l}\text { Number of respondents answering } \\
\text { (percent within category) }\end{array}$ \\
\hline \multicolumn{2}{|l|}{ State of operation $(n=231)$} \\
\hline Alabama & $13(5.6)$ \\
\hline Arkansas & $1(0.4)$ \\
\hline Florida & $18(7.8)$ \\
\hline Georgia & $25(10.8)$ \\
\hline Illinois & $2(0.9)$ \\
\hline Indiana & $14(6.1)$ \\
\hline Kentucky & $40(17.3)$ \\
\hline Michigan & $4(1.7)$ \\
\hline Mississippi & $6(2.6)$ \\
\hline North Carolina & $8(3.5)$ \\
\hline Ohio & $3(1.3)$ \\
\hline Oklahoma & $1(0.4)$ \\
\hline Oregon & $1(0.4)$ \\
\hline South Carolina & $10(4.3)$ \\
\hline Tennessee & $79(34.2)$ \\
\hline Texas & $4(1.7)$ \\
\hline Virginia & $1(0.4)$ \\
\hline Whole East Coast & $1(0.4)$ \\
\hline \multicolumn{2}{|l|}{ Respondent gender $(\mathrm{n}=171)$} \\
\hline Male & $130(76.0)$ \\
\hline Female & $41(24.0)$ \\
\hline \multicolumn{2}{|c|}{ Whether respondent $(\mathrm{n}=225)$ grows/buys/sells liners (respondents could choose more than one) } \\
\hline Grow liners & $126(56.0)$ \\
\hline Buy liners & $126(56.0)$ \\
\hline Sell liners & $46(20.0)$ \\
\hline Do not grow, buy, or sell liners & $31(15.0)$ \\
\hline \multicolumn{2}{|c|}{ Total number of acres of operation $(n=147)$} \\
\hline No acres & $33(22.9)$ \\
\hline 0.01 to 0.5 & $24(15.3)$ \\
\hline 0.51 to 5.0 & $48(33.3)$ \\
\hline 5.1 to 25 & $15(10.4)$ \\
\hline 25.1 to 100 & 17 (11.9) \\
\hline$\geq 100$ acres & $10(6.8)$ \\
\hline \multicolumn{2}{|c|}{ Percentage of production acreage dedicated to liner production $(\mathrm{n}=149)$} \\
\hline None & $37(24.8)$ \\
\hline $1 \%$ to $10 \%$ of production acreage & $57(38.3)$ \\
\hline $11 \%$ to $25 \%$ of production acreage & $20(13.4)$ \\
\hline $26 \%$ to $50 \%$ of production acreage & $18(12.1)$ \\
\hline $51 \%$ to $75 \%$ of production acreage & $3(2.0)$ \\
\hline $76 \%$ to $100 \%$ of production acreage & $14(9.4)$ \\
\hline \multicolumn{2}{|c|}{ Total number of liners purchased by respondent per year $(n=129)$} \\
\hline 0 to 100 liners & $10(7.8)$ \\
\hline 101 to 1,000 liners & $26(20.2)$ \\
\hline 1,001 to 5,000 liners & $38(30.0)$ \\
\hline 5,001 to 25,000 liners & $31(24.0)$ \\
\hline 25,001 to 100,000 liners & $16(12.4)$ \\
\hline 100,001 to $\geq 1$ million liners & $8(6.2)$ \\
\hline \multicolumn{2}{|c|}{ Number of suppliers from whom respondents purchase liners $(n=135)$} \\
\hline Do not buy liners & $3(2.2)$ \\
\hline 1 to 5 suppliers & $87(64.4)$ \\
\hline 6 to 10 suppliers & $29(22.0)$ \\
\hline 11 to 25 suppliers & $13(9.6)$ \\
\hline$\geq 26$ suppliers & $3(2.2)$ \\
\hline \multicolumn{2}{|c|}{ Total gross sales for respondents' firm $(n=155)$} \\
\hline Less than $\$ 50,000$ per year & $37(19.3)$ \\
\hline$\$ 50,001$ to $\$ 100,000$ per year & $19(9.9)$ \\
\hline$\$ 100,001$ to $\$ 250,000$ per year & $22(11.4)$ \\
\hline$\$ 250,001$ to $\$ 500,000$ per year & $19(9.9)$ \\
\hline$\$ 500,001$ to $\$ 750,000$ per year & $11(5.7)$ \\
\hline$\$ 750,001$ to $\$ 1$ million per year & $10(5.2)$ \\
\hline Over \$1 million per year & $34(17.7)$ \\
\hline Over $\$ 3$ million per year & $40(20.8)$ \\
\hline \multicolumn{2}{|c|}{ Percentage of total sales obtained by respondents' firm from liner sales $(n=188)$} \\
\hline Sales proportion not stated & $80(42.5)$ \\
\hline $1 \%$ to $10 \%$ of sales & $55(29.3)$ \\
\hline $11 \%$ to $25 \%$ of sales & $16(8.5)$ \\
\hline $26 \%$ to $50 \%$ of sales & $15(8.0)$ \\
\hline $51 \%$ to $75 \%$ of sales & $8(4.3)$ \\
\hline $76 \%$ to $99 \%$ of sales & $6(3.2)$ \\
\hline $100 \%$ of sales & $8(4.3)$ \\
\hline
\end{tabular}

(Continued on next page)
Liner caliper uniformity $=$ average caliper of the plants in the liner bundle is relatively the same: uniform or not uniform;

Liner canopy density uniformity $=$ average canopy density of the plants in the liner bundle is relatively the same: uniform or not uniform;

Region of production $=$ region of the country where liners were produced: southeastern United States, northwestern United States, or unspecified U.S. region; Price per liner $=$ cost per individual plant within the hypothetical nursery liner bundle: low price $=\$ 1.30$ per plant, midrange price $=\$ 1.60$ per plant, or high price $=$ $\$ 1.90$ per plant. Visual images portrayed unbundled bare-root liner representatives; and

Other $=$ other relevant demographic variables and demographics expected to influence product preference including whether the respondent grows, buys, or sells plant liners, annual gross sales, volume of annual liner purchases, type of liner stock preferred, gender, and years of green industry career experience.

Within the conjoint model, the intercept ( $\beta 0)$ represents the mean preference rating and coefficients of dummy variables calculated for each liner attribute (e.g., $\beta 1$ through $\beta 8)$ measure the deviation from the mean rating for that variable (Palma, 2002). Precision of the conjoint model can be further enhanced by integrating other important variables that influence preference and key demographic parameters identified with liner consumers, including respondent's production, purchasing and sales experience with nursery liners as well as the volume of liner purchased annually, volume of annual sales, gender, and years of experience the respondent has in the green industry. When these variables are pooled to become $\beta 9$ "respondent demographics" and included in a modified conjoint preference model, the equation is expressed as:

$$
\begin{aligned}
\text { Liner Rating }= & \beta 0+\beta 1 F O L R 2+\beta 2 F O L R 3 \\
& +\beta 3 \text { Height }+\beta 4 \text { Caliper } \\
& +\beta 5 \text { Canopy Density } \\
& +\beta 6 \text { SEUS Region } \\
& +\beta 7 N W U \text { S Region } \\
& +\beta 8 \text { Price } \\
& +\beta \text { Respondent } \\
& \text { Demographics }+V i
\end{aligned}
$$

where $\mathrm{V}_{\mathrm{i}}=$ the error term.

We used a two-limit Tobit model to account for the truncation residuals of the rating scale and to eliminate bias from estimating bounded ratings from an ordinary least squares model that assumes a normal distribution. Our modified Likert rating scale established lower and upper limits at 1 to 10 . The two-limit Tobit model estimates part worth values and allows any values lower than 1 to automatically be tallied as 1 , which is the lower tail censoring value. Parameters 
Table 2. (Continued) Demographic information provided by respondents participating in a survey investigating quality perceptions and ratings for $1+0$ bare-root nursery liner products at selected regional nursery trade shows and educational venues.

\begin{tabular}{|c|c|}
\hline Item & $\begin{array}{c}\text { Number of respondents answering } \\
\text { (percent within category) }\end{array}$ \\
\hline \multicolumn{2}{|c|}{ Number of years of green industry experience held by respondents $(\mathrm{n}=115)$} \\
\hline No years of experience & $3(2.6)$ \\
\hline Less than 1 to 5 years of experience & $27(23.5)$ \\
\hline 6 to 10 years of experience & $23(20.0)$ \\
\hline 11 to 25 years of experience & $43(37.4)$ \\
\hline$\geq 26$ years of experience & $19(16.5)$ \\
\hline \multicolumn{2}{|c|}{ Type of Stock preferred by respondents $(n=213)$ (respondents could choose more than one) } \\
\hline \multicolumn{2}{|c|}{ Bare-root } \\
\hline Preferred & $108(50.7)$ \\
\hline Not listed as a preference & $105(49.3)$ \\
\hline \multicolumn{2}{|l|}{ Cell pack (plug grown) } \\
\hline Preferred & $99(46.5)$ \\
\hline Not listed as a preference & $114(53.5)$ \\
\hline \multicolumn{2}{|l|}{ 3-inch $\left(414 \mathrm{~cm}^{3}\right)$ air root prune container } \\
\hline Preferred & $42(19.7)$ \\
\hline Not listed as a preference & $171(80.3)$ \\
\hline \multicolumn{2}{|c|}{ 4-inch rose $\left(798 \mathrm{~cm}^{3}\right)$ (band pot) container } \\
\hline Preferred & $20(9.4)$ \\
\hline Not listed as a preference & $193(90.6)$ \\
\hline \multicolumn{2}{|l|}{ 1-gal $(3.78 \mathrm{~L})$ air root prune container } \\
\hline Preferred & $35(16.4)$ \\
\hline Not listed as a preference & $178(83.6)$ \\
\hline \multicolumn{2}{|l|}{ 1-gal $(3.78 \mathrm{~L})$ trade standard container } \\
\hline Preferred & $69(32.3)$ \\
\hline Not listed as a preference & $144(67.6)$ \\
\hline
\end{tabular}

of the two-limit Tobit regression model are obtained by computing the maximum likelihood estimates (Palma, 2002). The log likelihood function for the censored regression model can be expressed as follows (Greene, 1990):

$$
\begin{aligned}
\ln L= & \sum_{Y_{i}>1}-\frac{1}{2}\left[\ln (2 \pi)+\ln \sigma^{2}+\frac{\left(Y_{i}-\beta^{\prime} X_{i}\right)^{2}}{\sigma^{2}}\right] \\
& +\sum_{Y_{i}=1} \ln \left[1-\phi\left(\frac{B^{\prime} X_{i}}{\sigma}\right)\right]
\end{aligned}
$$

\section{Results}

Respondents returned a total of 248 completed surveys from all venues, which provided a total of 3968 observations for conducting the conjoint experiment. Surveys were excluded from analysis if respondents failed to complete the visual survey assessment, failed to answer at least half of the demographic questions, or indicated that they personally did not buy, grow, or sell nursery liner stock. Survey respondents were mostly from southern states and were primarily male $(76 \%)$ with more than half of all respondents having more than 12 years of experience in the green industry. Of respondents who answered related questions, $\approx 85 \%$ had bought, sold, or grew nursery liners with approximately half of the respondents purchasing 5000 or more liners per year (Table 2). Approximately half of respondents who answered the question regarding their acreage reported that they produced liners on 20 or more acres (8.1 ha) of land, which corresponded to $\approx 6 \%$ of the total production operation (data not shown). For ease of analysis, acreage devoted to liner production, percentage of total production area available, and range data on liner purchase quantities were classified into six categories (Table 2). Among respondents who purchased liners, relatively few suppliers were used; on average respondents indicated that just two to four sources provided their nursery liner stock (Table 2). Half of respondents reported making less than $\$ 250,000$ per year, whereas $\approx 39 \%$ worked for firms earning in excess of $\$ 1$ million. Of these totals, only a small proportion was attributed to sales of liner stock with less than $20 \%$ of respondents reporting proportional earnings of greater than $25 \%$ attributed to liners. Only $\approx 4 \%$ reported total annual sales volume attributed to nursery liner stock (Table 2).

The model used in the study separates and estimates the contribution of each experimental variable to the respondent's preference rating for each of the products (Wirth et al., 2007). Within the model, the intercept term $(\beta 0=6.86)$ represents the mean preference rating combined for the average liner buyer. Parameter estimates for tested variables and other data reported by respondents that were expected to influence preferences for nursery liner stock were used to calculate the average "respondent demographics" value for study participants $(\beta 9=$ -0.92) (Tables 3, 4, and 5).

The model assumes values for the dependant variable (preference rating) on a scale of 1 to 10 . Three key liner attribute conditions, including high FOLR $(\mathrm{t}=17.2, P \leq 0.0001)$, height uniformity $(\mathrm{t}=4.5, P \leq 0.0001)$, and canopy density uniformity $(\mathrm{t}=6.4, P \leq$ 0.0001 ), significantly influenced hypothetical purchasing decisions (Table 3). Consistent with economic theory, all levels of parameter estimates for price, including the lowest price or $\$ 1.30$ per plant, received negative valuation $(-0.23)$ (Table 5) and decreased linearly with rising price (Table 3 ) (Wirth et al., 2007). Surprisingly, within our model, the price attribute was not statistically significant in affecting buyer decisions regarding hypothetical liner purchases $(\mathrm{t}=-0.8 ; P=0.42)$ (Table 3). A nonsignificant coefficient is an indication that the parameter had no effect on the preference rating (Wirth et al., 2007). Like with price, region of production $(\mathrm{t}=0.24$ to $-0.48 ; P=0.81$ to 0.63$)$ nor caliper uniformity $(\mathrm{t}=-1.26 ; P=0.21)$, and mid FOLR grade $(\mathrm{t}=-1.69 ; P=0.92)$ did not have a statistically significant influence on respondent preference for nursery liner attribute levels (Table 3 ).

Using the model parameter estimates, quality ratings were derived for each nursery liner product (Table 6) and were consistent with mean preference ratings given by respondents. The nursery liner product with the highest estimated preference overall among respondents was a liner bundle with high FOLR number, uniform height, uniform canopy density, mixed caliper, from an unspecified U.S. region, and that had the lowest price. When respondent demographics are included, the summed utility value for this product is: $\beta 06.86+1.49+0.25+0.07+$ $0.35+0.02-0.28-0.92=7.84$ (Tables 5 and $6)$. The rest of the variables were estimated at their mean values and represent values characteristic to the average study participant Ratings of holdout products were statistically compared with actual product ratings to demonstrate the model's predictability power (Wirth et al., 2007). The actual mean rating for the first holdout product $\left(\mathrm{HO}_{1}\right)$ was 7.26 $( \pm 0.19)$ versus the model's estimated rating of 7.64. The mean rating for the second holdout product $\left(\mathrm{HO}_{2}\right)$ was $3.43( \pm 0.22)$ versus the estimated rating of 3.84 (Table 6 ). The model was able to significantly explain variability among participant responses as evidenced by the log-likelihood value for the model, which was -2331.99 (Palma, 2002).

Relative importance weights of attributes, expressed as percentages, are another method of analyzing conjoint results (Wirth et al., 2007). Relative importance weights are calculated by first summing the minimum and maximum utility values for each attribute to determine a range for each of the six attributes. All six attribute ranges are then summed together. The relative importance weight of an attribute is the percentage of its range to the total sum of all six attribute ranges. Attribute importance weight calculations were consistent with other results from the study. First-order lateral root number was the most important attribute and was responsible for $65.4 \%$ of respondents' hypothetical purchase decisions. Canopy density and height uniformity were important attributes at $16.15 \%$ and $11.29 \%$, respectively. Region of production and price were not important to quality perceptions at $1.52 \%$ and $2.44 \%$, respectively (Table 7). 
Table 3. Parameter estimates of product preference ratings for $1+0$ bare-root nursery liners derived from data provided by respondents $(\mathrm{n}=248)$ participating in a survey administered at selected regional nursery trade shows and educational venues.

\begin{tabular}{|c|c|c|c|c|}
\hline Variable & Coefficient & Standard error & $\mathrm{t}$ value & $P$ value \\
\hline \multicolumn{5}{|l|}{ Intercept } \\
\hline$\beta 0$ & 6.865 & 0.40 & 17.19 & $\leq 0.0001$ \\
\hline \multicolumn{5}{|l|}{ Nursery liner attributes } \\
\hline Low FOLR & -1.347 & & & \\
\hline Mid FOLR & -0.144 & 0.09 & -1.69 & 0.092 \\
\hline High FOLR & 1.492 & 0.09 & 17.39 & $\leq 0.0001$ \\
\hline Uniform height & 0.245 & 0.05 & 4.47 & $\leq 0.0001$ \\
\hline Mixed height & -0.245 & & & \\
\hline Uniform caliper & -0.069 & 0.05 & -1.26 & 0.209 \\
\hline Mixed caliper & 0.069 & & & \\
\hline Uniform canopy density & 0.350 & 0.05 & 6.40 & $\leq 0.0001$ \\
\hline Mixed canopy density & -0.350 & & & \\
\hline Northwest U.S. region & -0.017 & 0.07 & 0.24 & 0.814 \\
\hline Southeast U.S. region & -0.041 & 0.09 & -0.48 & 0.630 \\
\hline Unspecified U.S. region & 0.024 & & & \\
\hline Price & -0.176 & 0.22 & -0.80 & 0.423 \\
\hline \multicolumn{5}{|l|}{ Respondent demographic attributes } \\
\hline Grew plant liners & -0.365 & 0.12 & -3.01 & 0.003 \\
\hline Bought plant liners & -0.162 & 0.14 & -1.19 & 0.232 \\
\hline Sold plant liners & 0.081 & 0.14 & 0.57 & 0.567 \\
\hline Annual liner purchase volume & 0.023 & 0.04 & 0.59 & 0.555 \\
\hline Annual liner sales & -0.036 & 0.02 & -1.58 & 0.115 \\
\hline Preference for bare-root liners & -0.015 & 0.13 & 0.11 & 0.911 \\
\hline Gender & -0.330 & 0.14 & -2.34 & 0.019 \\
\hline Green industry experience (years) & -0.018 & 0.01 & -3.11 & 0.002 \\
\hline
\end{tabular}

FOLR $=$ first-order lateral roots.

Table 4. Respondent means, parameter estimates, and calculated utility of demographic variable estimates derived from data provided by respondents $(n=248)$ participating in a survey administered at selected regional nursery trade shows and educational venues.

\begin{tabular}{lccc}
\hline Variable & Respondent mean & Parameter estimate & Calculated utility \\
\hline Grew plant liners & 0.635 & -0.365 & -0.231 \\
Bought plant liners & 0.676 & -0.162 & -0.110 \\
Sold plant liners & 0.243 & 0.081 & 0.020 \\
Annual liner purchase volume & $2.270^{\mathrm{z}}$ & 0.023 & 0.051 \\
Annual liner sales & $4.014^{\mathrm{y}}$ & -0.036 & -0.145 \\
Preference for bare-root liners & 0.662 & -0.015 & -0.010 \\
Gender & 0.757 & -0.330 & -0.250 \\
Green industry experience (years) & 15.104 & -0.018 & -0.264 \\
$\quad \beta 9$ "respondent demographics" & & & $\sum=-0.919$ \\
\hline
\end{tabular}

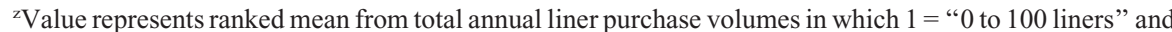
$6=$ " 100,001 to +1 million liners" purchased per year.

${ }^{\mathrm{y}}$ Value represents ranked mean from total gross sales values of firms where $1=$ "less than $\$ 50,000$ per year" and $8=$ "over $\$ 3$ million per year."

Table 5. Calculated utility of $1+0$ bare-root nursery liners stock attribute levels from parameter estimates derived from data provided by respondents $(n=248)$ participating in a survey administered at selected regional nursery trade shows and educational venues.

\begin{tabular}{llr}
\hline Attribute & \multicolumn{1}{c}{ Attribute level } & Utility \\
\hline FOLR number & Low FOLR (4 or 5) & -1.35 \\
& Mid FOLR 6 or 7) & -0.14 \\
Height uniformity & High FOLR (8 or 9) & 1.49 \\
& Uniform & 0.25 \\
Caliper uniformity & Nonuniform & -0.25 \\
& Uniform & -0.07 \\
Canopy density uniformity & Nonuniform & 0.07 \\
& Uniform & 0.35 \\
Region of production & Nonuniform & -0.35 \\
& Pacific Northwest U.S. & -0.02 \\
Price (per liner) & Southeast U.S. & -0.04 \\
& Unspecified U.S. & 0.02 \\
& \$1.30 per liner & -0.23 \\
& \$1.60 per liner & -0.28 \\
\hline
\end{tabular}

FOLR $=$ first-order lateral roots.
When asked to rank attributes of nursery liners as independent contributors to quality, many individual attributes reflected results of the conjoint study. Self-reported mean attri- identified as the second most important attribute (3.87) with price per liner ranked third most important to liner purchase decisions (3.86). Perceived importance of a uniform canopy density, however, demonstrated a marked departure from the conjoint study outcome and, when considered independently, ranked as the fourth most important attribute (3.83). Region of production was stated as the least important factor to consider when selecting nursery liners (3.03) (Table 7).

\section{Discussion}

Results from both the self-stated importance ratings and the visual survey portion were consistent with higher FOLR numbers being the most important product attribute green industry professionals assess when making purchasing decisions concerning bareroot nursery liners. The observation that high FOLR counts are important as a grading criterion is consistent with previous research. First-order lateral root number can be a reliable grading criterion (Clark et al., 2000) and is a reliable indicator of potential outplanting success (Clark et al., 2000; Dumroese et al., 2005; Jacobs et al., 2005; Kormanik et al., 1998; Thompson and Schultz, 1995; Wilson and Jacobs, 2006).

During preliminary informal surveys at the outset of this project, uniformity of liner attributes was identified as important to liner buyer perceptions concerning quality. In selfreported importance ratings based on individual liner attributes, liner height uniformity was identified as the second highest preferred product attribute. In contrast, liner height was ranked third in importance through conjoint analyses after uniform canopy density. A higher preference for uniform liner canopy density likely reflects green industry professionals' expectations about the future growth and performance of the plant. Although branching and canopy shape can be controlled by pruning, any additional management steps required to produce the crop increases labor costs. Because initial branch structure forms the base architecture of the plant, if branch structure throughout the crop is uniform, an end-user can anticipate good canopy architecture in the finished crop with less pruning effort.

Surprisingly, caliper uniformity was not very important to hypothetical purchasing decisions. A possible explanation could be the method in which the survey was given. Although photographs visually depicted a products' respective attribute levels, these aspects were also printed on each product image. Thus, although liner caliper uniformity, or nonuniformity, was clearly stated, it might have been difficult for respondents to visualize differences in caliper size among the pictured liner products. Future survey efforts might benefit from hands-on examinations of carefully selected live plant material. Respondents would then be able to more accurately discern differences in caliper and be able to make more discriminatory decisions. bute scores confirmed that FOLR was expected to be the most important attribute when respondents were making purchasing decisions (4.22). Liner height uniformity was 
Table 6. Estimated preference ratings for $1+0$ bare-root nursery liner products with associated attribute level utility values presented in the visual display (ratings were ranked in order of highest to lowest for comparison purposes).

\begin{tabular}{|c|c|c|c|c|c|c|c|c|c|}
\hline $\begin{array}{l}\text { Product } \\
\text { (image) }\end{array}$ & $\begin{array}{l}\text { FOLR } \\
\text { number }\end{array}$ & $\begin{array}{l}\text { Liner ht } \\
\text { uniformity }\end{array}$ & $\begin{array}{c}\text { Liner caliper } \\
\text { uniformity }\end{array}$ & $\begin{array}{c}\text { Liner canopy } \\
\text { uniformity }\end{array}$ & $\begin{array}{l}\text { Region of } \\
\text { production }\end{array}$ & $\begin{array}{l}\text { Liner } \\
\text { price }\end{array}$ & Intercept & $\begin{array}{c}\text { Respondent } \\
\text { demographics }\end{array}$ & $\begin{array}{c}\text { Estimated } \\
\text { rating } \\
\end{array}$ \\
\hline $15(12)$ & 1.49 & 0.25 & 0.07 & 0.35 & 0.02 & -0.28 & 6.86 & -0.92 & 7.84 \\
\hline $16(7)$ & 1.49 & 0.25 & -0.07 & 0.35 & 0.02 & -0.23 & 6.86 & -0.92 & 7.75 \\
\hline $13(9)$ & 1.49 & -0.25 & 0.07 & -0.35 & -0.04 & -0.23 & 6.86 & -0.92 & 6.63 \\
\hline $14(16)$ & 1.49 & -0.25 & -0.07 & -0.35 & -0.04 & -0.23 & 6.86 & -0.92 & 6.49 \\
\hline $11(13)$ & -0.14 & 0.25 & 0.07 & 0.35 & -0.02 & -0.28 & 6.86 & -0.92 & 6.17 \\
\hline $9(6)$ & -0.14 & -0.25 & 0.07 & 0.35 & 0.02 & -0.23 & 6.86 & -0.92 & 5.76 \\
\hline $10(8)$ & -0.14 & -0.25 & -0.07 & 0.35 & 0.02 & -0.33 & 6.86 & -0.92 & 5.52 \\
\hline $12(15)$ & -0.14 & 0.25 & -0.07 & -0.35 & -0.04 & -0.23 & 6.86 & -0.92 & 5.36 \\
\hline $8(2)$ & -1.35 & 0.25 & -0.07 & 0.35 & 0.02 & -0.23 & 6.86 & -0.92 & 4.91 \\
\hline $6(3)$ & -1.35 & 0.25 & 0.07 & 0.35 & -0.04 & -0.33 & 6.86 & -0.92 & 4.89 \\
\hline $2(5)$ & -1.35 & -0.25 & 0.07 & 0.35 & 0.02 & -0.23 & 6.86 & -0.92 & 4.55 \\
\hline $4(1)$ & -1.35 & -0.25 & -0.07 & 0.35 & -0.04 & -0.28 & 6.86 & -0.92 & 4.31 \\
\hline $5(4)$ & -1.35 & 0.25 & 0.07 & -0.35 & 0.02 & -0.33 & 6.86 & -0.92 & 4.25 \\
\hline 7 (17) & -1.35 & 0.25 & -0.07 & -0.35 & 0.02 & -0.23 & 6.86 & -0.92 & 4.21 \\
\hline $1(10)$ & -1.35 & -0.25 & 0.07 & -0.35 & 0.02 & -0.23 & 6.86 & -0.92 & 3.85 \\
\hline $3(11)$ & -1.35 & -0.25 & -0.07 & -0.35 & 0.02 & -0.28 & 6.86 & -0.92 & 3.66 \\
\hline $\mathrm{HO}_{1}(14)$ & 1.49 & 0.25 & -0.07 & 0.35 & -0.04 & -0.28 & 6.86 & -0.92 & 7.64 \\
\hline $\mathrm{HO}_{2}(18)$ & -1.35 & -0.25 & 0.07 & -0.35 & 0.02 & -0.23 & 6.86 & -0.92 & 3.84 \\
\hline
\end{tabular}

FOLR $=$ first-order lateral roots.

Table 7. Utility range and relative importance of $1+0$ bare-root nursery liner attributes compared with self-stated independent importance ratings to better describe how these factors influence respondent acceptance (numbers in parentheses represent ranked order of ratings from highest to lowest for comparison purposes).

\begin{tabular}{lccc}
\hline Attribute & Utility range & Relative importance (\%) & $\begin{array}{c}\text { Self-stated independent } \\
\text { importance rating (1-5 scale) }\end{array}$ \\
\hline FOLR number & 2.84 & $65.43(1)$ & $4.22(1)$ \\
Canopy density uniformity & 0.70 & $16.15(2)$ & $3.83(4)$ \\
Height uniformity & 0.49 & $11.29(3)$ & $3.87(2)$ \\
Caliper uniformity & 0.14 & $3.17(4)$ & $3.79(5)$ \\
Price & 0.11 & $2.44(5)$ & $3.86(3)$ \\
Region of production & 0.07 & $1.52(6)$ & $3.03(6)$ \\
\hline
\end{tabular}

FOLR $=$ first-order lateral roots.

Contrary to prestudy hypotheses, production region was relatively unimportant to simulated purchasing decisions. Both the southeastern and Pacific Northwest U.S. regions imparted a negative impact to perceived product utility. We interpret that an unspecified region of production might be more acceptable to a nursery liner end-user as a result of preconceived notions about certain U.S. regions. For example, if a buyer is evaluating a liner bundle from the Pacific Northwest, that buyer might make the assumption that incurred shipping costs would be too high to positively influence the final purchase commitment.

Respondent preference ratings for individual attributes indicate that price is considered important to nursery liner buyers when making purchasing decisions. Results from conjoint analysis, however, indicate that the price range we selected contributed just $2.4 \%$ to overall hypothetical purchasing decisions. This contradiction may be partly explained by the similarity between our hypothetical price ranges and those encountered by nursery liner buyers. Although the midlevel price of $\$ 1.60$ per liner was consistent with 2006 nursery catalog listings for many $1+0$ Nuttall oak liner species, our high and low values were set at just $20 \%$ above and below contemporary costs. If the low and high price were set to more extreme differences, price per liner might have been perceived to be of greater importance to purchasing decisions.
Other relevant demographic variables, for example whether a respondent grows, buys, or sells liners as well as years of experience in the green industry, are expected to influence preferences for nursery plant liners. We can increase the explanatory power of simulation analysis models by including key demographic variables in calculations of an aggregate average for typical respondents in a surveyed region $(\beta 9)$. In turn, calculated utility values for each product more accurately predict potential product acceptance in different markets.

Ultimately, buyer use for a crop of bareroot $1+0$ nursery liners is calculated by adding the sum of selected liner product attribute utility values to the model intercept and the aggregate average for the demographic mean values, which describes the mean utility value (Wirth et al., 2007). From our model, the premium first choice product that had the highest perceived utility was a liner product with a high FOLR number, a uniform canopy density and height, from an unspecified region, and at the lowest price. Subgrades from within the crop could then be selected based on expected buyer preferences for subpremium products. By allowing growers to establish baseline parameters for grading purposes, they will also be able to modify production and grading techniques such as undercutting or altering bed planting densities (Clark et al., 2000; Dumroese et al., 2005; Jacobs et al., 2005; Kormanik et al.,
1998; Thompson and Schultz, 1995; Wilson and Jacobs, 2006) that emphasize the most desirable product attributes.

As was apparent from our two holdout products $\left(\mathrm{HO}_{1}\right.$ and $\left.\mathrm{HO}_{2}\right)$, our model's predictive ability closely approximated actual respondent preference valuations; therefore, we are confident that nursery liner growers can reliably integrate knowledge about buyer preference for these key liner attributes to more accurately evaluate the quality of their field-dug liners. These findings can be directly applied to better estimate end-user acceptance and market value for their bareroot liner products. Analysis of the holdout products further suggests that a product with a high FOLR count, overall product uniformity of liner height and canopy density, and a relatively low to midrange price per plant for the species will be desirable to nursery liner buyers. Also, because we did not specify the plant species during the survey, the use of this model should apply across several deciduous tree species, allowing liner growers to judge a variety of different crops.

\section{Literature Cited}

American Nursery and Landscape Association (ANLA). 2004. American standard for nursery stock. ANSI Z60.1-2004. Washington, DC. 24 Mar. 2009. <http://www.anla.org/applications/ Documents/Docs/ANLAStandard2004.pdf $>$.

Behe, B., R. Nelson, S. Barton, C.R. Hall, C.D Safley, and S. Turner. 1999. Consumer preferences for geranium flower color, leaf variegation, and price. HortScience 34:710-742.

Clark, S.L., S.E. Schlarbaum, and P.P. Kormanik. 2000 . Visual grading and quality of $1+0$ Northern Red Oak seedlings. Southern J. Appl. For. 14:93-97.

Curry, J. 1996. Understanding conjoint analysis in 15 minutes. Sawtooth Software, Res. Paper Ser. Quirk's Marketing Research Review. Sawtooth Software Inc., Ketchum, ID.

Dumroese, R.K., D.F. Jacobs, and T.D. Landis. 2005. Successful stock production for forest regeneration: What foresters should ask nursery managers about their crops (and vise versa). 
In: Colombo, S.J. (ed.). A symposium on the state-of-the-art in reforestation proceedings, 26-28 July 2005. For. Res. Info. Paper No. 160. Ontario Ministry Nat. Resour. Ontario For. Res. Inst., Sault Ste. Marie, Ontario, Canada.

Garber, M.P., J.M. Ruter, and J.T. Midcap. 1999. Production and marketing of field grown trees in Georgia. Univ. Georgia Coll. Agr. Envir. Sci. Coop. Ext. Serv. 31 Aug. 2008. <http://pubs. caes.usa.edu/caespubs/pubcd/B1115-w.htm>.

Greene, W.H. 1990. Econometric analyses. MacMillan Publishing Co, New York, NY.

Jacobs, D.F., K.F. Salifu, and J.R. Seifert. 2005. Relative contribution of initial root and shoot morphology in predicting field performance of hardwood seedlings. New For. 30:235-251.

Kormanik, P.P., S.-J.S. Sung, D.J. Kass, and S. Schlarbaum. 1998. Effect of seedling size and FOLR on early development of northern red oak on mesic sites. In: Waldrop, T.A. (ed.) Proc. of the ninth biennial southern silvicultural research conference, 25-27 Feb. 1997. Gen. Tech. Rep. SRS-20. USDA-For. Serv. Southern Res. Sta., Asheville, NC.

Mason, S.C., T.W. Starman, R.D. Lineberger, and B.K. Behe. 2008. Consumer preferences for price, color harmony, and care information of container gardens. HortScience 43:380-384.

Palma, M.A.G. 2002. Market preferences toward farm-raised sturgeon in the southeastern United States: A conjoint analysis, Univ. FL, Gainesville, FL. MS Thesis.

Schultz, R.C. and J.R. Thompson. 1996. Effect of density control and undercutting on root morphology of $1+0$ bareroot hardwood seedlings: Five year field performance of root-graded stock in the central USA. New For. 13:297-310.
SPSS. 2005. SPSS Vers. 13.0 for Windows. SPSS Inc., Chicago, IL.

Thompson, J.R. and R.C. Schultz. 1995. Roots system morphology of Quercus rubra L. planting stock and 3-year field performance in Iowa. New For. 9:225-236.

TSP International. 2003. TSP software (vers. 4.5). Palo Alto, CA.

Wally, K., S. Parsons, and M. Bland. 1999. Quality assurance and the consumer: A conjoint study. Br. Food J. 101:148-161.

Wilson, B.C. and D.F. Jacobs. 2006. Quality assessment of temperate zone deciduous hardwood seedlings. New For. 31:417-433.

Wirth, F.F., L.A. Love, and M.A. Palma. 2007. Purchasing shrimp for at-home consumption: The relative importance of credence versus physical product features. Aquatic Econ. Mgt. 11:17-37. 